\title{
NEOPENTECOSTALISMO E RELIGIÕES AFRO- BRASILEIRAS: SIGNIFICADOS DO ATAQUE AOS SÍMBOLOS DA HERANÇA RELIGIOSA AFRICANA NO BRASIL CONTEMPORÂNEO*
}

Vagner Gonçalves da Silva

\section{Introdução}

O neopentecostalismo, em conseqüência da crença de que é preciso eliminar a presença e a ação do demônio no mundo, tem como característica classificar as outras denominações religiosas como pouco engajadas nessa batalha, ou até mesmo como espaços privilegiados da ação dos demônios, os quais se "disfarçariam" em divindades cultuadas nesses sistemas. É o caso, sobretudo, das religiões afro-brasileiras, cujos deuses, principalmente os exus e as pombagiras, são vistos como manifestações dos demônios. Uma outra face desse processo é, paradoxalmente, a "incorporação" da liturgia afro-brasileira nas práticas neopentecostais de algumas igrejas. Neste trabalho, pretendo analisar as relações de proximidade e antagonismo existentes entre estes dois campos religiosos, o neopentecostal e o afro-brasileiro, e suas conseqüências na transformação de certo imaginário brasileiro construído a partir dos valores aí existentes.

Em primeiro lugar, é bom que se diga que a visão das igrejas neopentecostais sobre as religiões afro-brasileiras é conseqüência do desenvolvimento do sistema teológico e doutrinário do pentecostalismo, surgido no Brasil no início do século XX, sobretudo a partir das décadas de 1950 e 1960. Nessa época, o movimento religioso assumiu novos contornos, expandindo a base de suas igrejas, adensando o número de denominações e ganhando maior visibilidade. Ao se distinguir pela ênfase do dom da cura divina (por isso chamada muitas vezes de "igrejas da cura") e pelas estratégias de proselitismo e conversão em massa, essa segunda onda ${ }^{1}$ do pentecostalismo preservou as características básicas do movimento que já tinha 40 anos, como a doutrina dos dons carismáticos (fé, profecia, discernimento, cura, línguas etc.), o sectarismo e o ascetismo (Mariano 1999:31).

A terceira fase do movimento pentecostal, iniciada nos anos de 1970, com grande projeção nas duas décadas seguintes, foi marcada por algumas 
diferenças significativas no perfil das igrejas surgidas e nas práticas adotadas, o que lhe valeu a classificação de "neopentecostal". Com o acréscimo do prefixo latino "neo", pretendeu-se expressar algumas ênfases que as igrejas identificadas nessa fase assumiram em relação ao campo do qual, em geral, faziam parte: abandono (ou abrandamento) do ascetismo, valorização do pragmatismo, utilização de gestão empresarial na condução dos templos, ênfase na teologia da prosperidade, utilização da mídia para o trabalho de proselitismo em massa e de propaganda religiosa (por isso chamadas de "igrejas eletrônicas") e centralidade da teologia da batalha espiritual contra as outras denominações religiosas, sobretudo as afro-brasileiras e o espiritismo.

Mas por que a escolha dessas religiões como principal alvo? Será que uma igreja tão organizada e interessada na conversão em massa, como a Igreja Universal do Reino de Deus (IURD) ${ }^{2}$, principal representante do segmento neopentecostal, iria se importar com religiões (candomblé, umbanda e espiritismo) que juntas, segundo o Censo Demográfico do IBGE de 2000, somam apenas 1,7 \% da população? Ainda que consideremos estes valores subestimados pelos motivos históricos que geraram o duplo pertencimento dos adeptos às religiões afro-brasileiras e ao catolicismo, o ataque neopentecostal não seria "muita pólvora para pouco passarinho"? Ou seja, o "bom combate" a ser travado não seria contra o catolicismo que, apesar da diminuição de fiéis verificada nas duas últimas décadas, ainda representa, segundo as mesmas fontes, 73,7 \% da população? Como declarar guerra aberta a esse monopólio religioso que possui vínculos com diversas esferas da sociedade brasileira? O episódio do "chute na santa" e suas repercussões negativas (Mariano 1999:81) são um bom exemplo da dificuldade do enfrentamento aberto.

$\mathrm{O}$ ataque às religiões afro-brasileiras, mais do que uma estratégia de proselitismo junto às populações de baixo nível socioeconômico, potencialmente consumidoras dos repertórios religiosos afro-brasileiros e neopentecostais, é conseqüência do papel que as mediações mágicas e a experiência do transe religioso ocupam na própria dinâmica do sistema neopentecostal em contato com o repertório afro-brasileiro. O desenvolvimento recente do catolicismo carismático atestaria a demanda crescente por tais mediações também nesse segmento religioso majoritário. No Brasil, enquanto os processos de secularização e racionalização atingiam os setores cristãos (catolicismo, protestantismo histórico etc.), o pentecostalismo surgiu como uma possibilidade, ainda tímida na primeira e segunda fases, mas muito forte na terceira, de valorização da experiência do avivamento religioso. No neopentecostalismo, essa característica radicaliza-se em termos de transformá-la 
em uma religião da experiência vivida no próprio corpo, característica que tradicionalmente esteve sob a hegemonia das religiões afro-brasileiras e do espiritismo kardecista. Combater essas religióes pode ser, portanto, menos uma estratégia proselitista voltada para retirar fiéis deste segmento embora tenha esse efeito - e mais uma forma de atrair fiéis ávidos pela experiência de religiões com forte apelo mágico, extáticas, com a vantagem da legitimidade social conquistada pelo campo religioso cristão.

Entre o neopentecostalismo e as religiões afro-brasileiras há, portanto, muitas diferenças, mas são as semelhanças entre estes campos que este artigo pretende analisar. Ou seja, julgo possível entender algumas dimensões da visão antagônica do pentecostalismo sobre denominações afro-brasileiras (a qual se expressa, muitas vezes, por meio da violência simbólica e mesmo física) partindo da análise do trânsito de certos "termos" entre os sistemas religiosos em conflito. Esse trânsito tem sido objeto de vários estudos recentes, nos quais me baseio para sistematizar os argumentos apresentados, além da observação de campo e da literatura de divulgação religiosa produzida nos meios neopentecostais.

\section{O "demônio" nos livros}

A visão demoníaca das religiões afro-brasileiras, propagada pelo neopentecostalismo, já estava presente nas fases anteriores do movimento pentecostal como elemento da teologia da cura divina. A cura, sendo uma das partes constitutivas do ritual da benção aos doentes, servia para mostrar a vitória de Deus sobre o demônio, geralmente identificado com a umbanda e o candomblé (Rolim 1990:49). Nesse período, entretanto, não se convocavam os "exércitos de Cristo" para saírem às ruas e impedirem rituais afro-brasileiros, ou mesmo tentar fechar terreiros, como tem ocorrido nas duas últimas décadas.

Um dos indícios do acirramento desse antagonismo contra as religiões afro-brasileiras pode ser identificado na publicação do livro Mãe-de-santo (1968), do missionário canadense Walter Robert McAlister, fundador da Igreja Pentecostal de Nova Vida no Rio de Janeiro, em 1960. Conforme consta no prefácio do livro:

Esta é a incrível história de uma baiana, cuja marca de faca, em seu braço direito, predestina-a desde o nascimento a ser mãe-de-santo, servindo os orixás e sacrificando aos exus a partir dos nove anos de idade. Nesta quarta edição, reestruturada, você vai sentir a repugnância experimentada por Georgina 
Aragão dos Santos Franco, ao ser enclausurada num quarto fétido, cheirando a sangue seco, sangue este com que lhe cobriram o corpo inteiro, ao 'fazer o santo'. Adivinhará depois toda sua alegria e euforia, quando finalmente descobriu não mais pertencer sua alma ao diabo, pois o sangue de Jesus Cristo passou a ser em sua vida mais forte e poderoso que quaisquer oferendas, vôos ou obrigações. Estou convencido de que você voltará muitas vezes a ler esse livro, como também o passará às mãos de amigos, parentes ou conhecidos que seguem as seitas afro-brasileiras. Aliás, este é um livro que todo brasileiro deve ler (1983 [1968]:5). ${ }^{3}$

Aqui os temas centrais desse antagonismo estão postos: 1. Identificação das divindades do panteão afro com o demônio; 2. Libertação pelo poder (maior) do sangue vivo de Jesus (em oposição ao sangue "seco" ou "fétido" da iniciação ou das oferendas); 3. Em conseqüência da libertação, a conversão. McAlister escreve que ao tomar contato no Brasil com a "macumba", inicialmente achou tratar-se de "folclore", depois, ao curar uma mulher cuja perna estava paralisada desde que ela dera um pontapé em um despacho, percebeu o quanto essas "crendices" eram nocivas e reais.

Comecei, a partir daí, a ter contato direto com vítimas do Candomblé e da Umbanda, que me contaram do drama terrível que é submeter-se às influências dos exus e orixás. Foi assim que passei da atitude de certa incredulidade para a conscientização de que aquelas narrativas não eram apenas resultado de imaginação, e não obstante as raízes supersticiosas, seus efeitos eram reais (1983 [1968]:10)

Esta seria então a quarta característica importante dessa "batalha espiritual": não se trata de ver as religiões afro-brasileiras como folclore, crendice popular, ignorância ou imaginação, mas reconhecer que suas divindades "existem", embora sejam "na verdade" "espíritos demoníacos" que enganam e ameaçam o povo brasileiro.

Creio que o Brasil tem que se libertar desse mal que já domina - segundo atestam algumas autoridades - mais de um terço da população, que se curva perante pais e mães-de-santo e obedecem às leis e ordens dos orixás. É às vítimas do poder diabólico do Candomblé e da Umbanda, portanto, que dedico este livro (1983 [1968]:11).

A convocação de libertação, como se vê, é feita em nível nacional, sendo esta outra característica da ação evangelizadora neopentecostal. 
Não me estenderei aqui sobre o livro de McAlister. Basta dizer que a mãede-santo Georgina poderia ser vista como um tipo ideal weberiano, na medida em que por meio dela percebe-se o perfil do desenvolvimento do candomblé na região Sudeste. Georgina é negra, nascida na Bahia, "sede desta religião no Brasil", é predestinada a ser do candomblé na dupla função de herdeira dos orixás de sua avó e sacerdotisa deste culto. Vem para o Rio de Janeiro, onde freqüenta o candomblé e a umbanda, assiste a um culto do pastor McAlister e durante um ano transita entre a igreja e o terreiro, mostrando o quanto lhe foi difícil abandonar a prática religiosa anterior. Finalmente, aceita a "ceia do Senhor" e passa a se dedicar a pregar a nova verdade para seus antigos irmãos de "fé espírita". Ao descrever este ponto da vida de Georgina, o livro parece atingir o clímax, quando a heroína, a pedido de outra mãe-de-santo recém-convertida, destrói impiedosamente o peji (altar) do terreiro desta.

McAlister descreve nesse livro as fontes do espiritismo ${ }^{4}$ no Brasil e localiza na bíblia as passagens que justificariam sua condenação. Curiosamente, alega que certas cerimônias do candomblé — como o ossé (rito de purificação pela água) e o sacrifício de animais sobre a pedra (otá) — foram "roubadas" de antigas leis de Deus presentes em livros do Velho Testamento, como o Levítico. Estas leis foram, entretanto, reformuladas por Jesus Cristo, cujo sacrifício final sinalizou para a salvação e a purificação de todos os que nele crêem. Nos dois capítulos centrais do livro, o relato é feito pela própria Georgina, que revela os rituais de sua antiga religião aos quais se submeteu ou que realizou, como a iniciação (rituais de raspagem de sua cabeça para Oxum, que incluíram banhos com ervas e com sangue), os trabalhos feitos em cemitérios, despachos com miolo de boi, com bonecas para amarração etc. Ao final, revela que [...] o povo do candomblé acredita que o poder dos "trabalhos" está nos segredos que a mãe-de-santo aprende através dos votos feitos aos orixás. Hoje sei perfeitamente que "segredos" são esses, e qual a sua fonte [...]: por trás dos sacrifícios sangrentos, das oferendas, comidas e banhos de ervas; enfim, por trás de todas as "obrigações", há um poder maligno e diabólico em ação. O povo acredita que os orixás são deuses, mas não entende que na realidade são forças do mal forcejando por entrar em suas vidas a fim de as controlar e depois destruir (1983 [1968]:93).

Georgina, espécie de "alter ego" de McAlister, reproduz no trecho acima a lógica do próprio candomblé, na qual são os ebômis (mais velhos no culto) que, detentores dos segredos do culto, os revelam aos poucos, de acordo com a senioridade dos seus interlocutores e segundo as relações de poder no interior da comunidade religiosa. Mas, sendo ela uma "mãe-de-santo convertida", a legitimidade de sua revelação radical (o "segredo dos segredos") apóia-se 
simultaneamente em dois sistemas de legitimação: o afro-brasileiro e o pentecostal. Por isso, o livro é uma peça de diálogo e sobreposição desses dois sistemas religiosos: nos capítulos centrais, aparece Georgina em sua "jornada para Deus" descrita em primeira pessoa; nos capítulos iniciais e finais, surge o relato de McAlister em sua jornada para os recônditos do Diabo (candomblé e a umbanda) para condená-los e convidar seus praticantes à libertação.

Além de pioneiro neste tipo de produção literária ${ }^{5}$, McAlister parece ter sido também o primeiro a utilizar a possessão in loco dos fiéis, durante sua pregação evangélica, como peça de enfrentamento dos demônios supostamente advindos dos cultos afros. Segundo Ricardo Mariano (1999:131), esse pastor, na época, "já obrigava os demônios a se manifestarem nos cultos públicos, conversava com eles, descobria seus nomes e os identificava com os cultos afro-brasileiros e espíritas".

O impacto das práticas da Igreja de Nova Vida no desenvolvimento desse antagonismo contra as religiões afro-brasileiras foi, entretanto, reduzido. Essa Igreja, apesar de utilizar o rádio e posteriormente ser uma das pioneiras no uso da televisão para transmitir sua mensagem evangélica, nunca teve uma grande expansão e sobreviveu modestamente após a morte do seu fundador em 1993. Sua contribuição maior foi a formação de importantes lideranças, como Edir Macedo e Romildo Ribeiro Soares, que posteriormente fundaram suas próprias igrejas e se tornaram famosos partindo dos pressupostos de evangelização em relação às religiões afro-brasileiras aprendidos com McAlister.

Edir Macedo, de origem católica e com passagem pela umbanda, havia se convertido à Nova Vida, na qual ficou por mais de uma década (Freston 1994:131; Mariano 1999:54). Dissidente desta igreja fundou, em 1977, juntamente com Romildo Soares e Roberto Lopes, a Igreja Universal do Reino do Deus. Porém, disputas pelo poder ocasionaram a dissolução do triunvirato, ficando a igreja sob o comando exclusivo de Edir Macedo. Nas décadas seguintes, aliando uma tática agressiva de proselitismo, investimento na mídia televisiva e acirramento da guerra espiritual contra as denominações rivais, a Universal tornou-se a mais conhecida e influente igreja do movimento neopentecostal. Na mídia impressa, o ataque iniciou-se desde as primeiras publicações da Igreja. Como menciona Ronaldo Almeida (1996:38):

A primeira publicação da Igreja Universal foi a revista Plenitude, criada pouco tempo depois da sua fundação e, desde o seu primeiro número, o ataque à Umbanda e ao Candomblé imperaram como matérias principais. A Folha Universal, que substituiu posteriormente a revista, traz todas as semanas diversas reportagens a respeito dos males causados por estas religiões. 
É da autoria de Edir Macedo o principal e mais contundente livro de oposição aos cultos afro-brasileiros: Orixás, caboclos \& guias. Deuses ou demônios? ${ }^{6}$ Lançado em 1988, esse livro, cuja vendagem já teria chegado a 3 milhões de exemplares ${ }^{7}$, foi motivo de processo judicial, tendo sido "finalmente liberado pela justiça", como se lê na capa. Uma síntese do perfil do autor e do livro é fornecida no prefácio de J. Cabral:

\footnotetext{
Através dos veículos de comunicação e das igrejas que tem estabelecido pelos rincões de nossa pátria e no exterior, o bispo Macedo tem desencadeado uma verdadeira guerra santa contra toda obra do diabo. Nesse livro denuncia as manobras satânicas através do kardecismo, da Umbanda, do Candomblé e outras seitas similares; coloca a descoberto as verdadeiras intenções dos demônios que se fazem passar por orixás, exus, erês, e ensina a fórmula para que a pessoa se liberte do seu domínio (apud Macedo 1996 [1988]:20).
}

Orixás, caboclos \& guias. Deuses ou demônios? retoma a estrutura e os temas centrais de Mãe-de-santo. Porém, pretendendo não deixar nem sombra de dúvida sobre a "resposta certa" à pergunta do título, apresenta argumentos mais detalhados, em um tom muito mais agressivo de condenação e alerta sobre os perigos que correm os que cultuam o panteão mencionado.

Segundo a exegese bíblica contida no livro de Macedo, os demônios existem e são criaturas de Deus que, por invejarem o criador, caíram em desgraça e vivem a disputar desde então o trono celeste. Como espíritos sem corpo, procuram apoderar-se dos corpos dos homens para causar-lhes doenças, infortúnios e afastá-los de Deus. A luta dos homens contra os demônios é, portanto, uma decorrência da guerra destes contra Deus. Além disso, a vitória sobre o demônio significa, para os homens, dar o devido valor ao sacrifício feito por Jesus em nome de toda a humanidade — daí ser em nome deste (do seu sangue sacrificial) que se invoca a vitória sobre o mal e a posse da salvação eterna.

Para Macedo, os diabos se apoderam dos homens especialmente quando estes freqüentam terreiros de candomblé, umbanda e espíritas ou realizam práticas de magia (como trabalhos e despachos); têm, ou tiveram, pessoas da família ou próximas envolvidas com esta prática (no caso de pessoas da família, mesmo quando estas já morreram, o demônio pode atacar seus parentes; nessa circunstância, diz-se que é um "demônio hereditário"); comeram comidas ofertadas aos orixás e, em resumo, não aceitaram Jesus plenamente em seu coração, ou seja, não têm o Espírito Santo em sua vida. Entretanto, mesmo quando estes fatores propiciatórios estão ausentes, a possessão demoníaca poderá ocorrer simplesmente por "maldade do próprio demônio". As "evidências" de que as religiões afro-brasileiras são diabólicas 
decorrem da realização de sacrifícios de animais, transe de possessão por espíritos, culto aos mortos, uso da magia para fazer malefícios etc.

A exemplo do livro Mãe-de-santo, no de Macedo há uma descrição que se pretende "objetiva" dessas religiões, baseada em inúmeros testemunhos de ex-membros dos cultos afros que se converteram à IURD ${ }^{8}$, na própria experiência do autor como ex-participante da umbanda e em um caderno (manuscrito) de "fundamentos" ("conhecimentos secretos") doado por uma ex-mãe-de-santo ao autor. ${ }^{9}$

Para além das semelhanças existentes entre os livros de McAlister e Macedo $^{10}$, o que torna a publicação do segundo mais convincente para os objetivos pretendidos é o uso de uma farta ilustração que se vale do próprio status da dimensão estética e ritualística das religiões afro-brasileiras para julgá-las como demoníacas. Na capa, uma foto do orixá Oxalá (paramentado de branco) é reproduzida sobre um fundo vermelho e preto (cores de Exu) ${ }^{11}$, tendo à sua frente a estátua de um caboclo e de São Jorge, fios de contas, quartinhas etc. Ao centro, uma caveira é rodeada por velas acesas em círculo. Obviamente, trata-se de uma montagem de peças na forma estilizada de um "despacho" e, por isso mesmo, seu poder imagético é bastante sugestivo, sobretudo pelas associações que induz por meio de coisas funestas (a caveira); ameaçadoras (o caboclo com a sua clave erguida em posição de combate); misteriosas (os elementos litúrgicos).

No interior do livro, as legendas que acompanham as fotos pretendem desvendar-lhes os "significados verdadeiros". No início do livro, por exemplo, a reprodução de um convite para uma festa de candomblé, tendo um tridente como emblema, apresenta a seguinte legenda: "O tridente do diabo revela o intuito deste ritual" (:27). Uma foto de imagem de pombagira é seguida pelas frases: "A pomba-gira causa em muitas mulheres o câncer de útero, ovário, frigidez sexual e outras doenças. À sua atuação atribuem-se comportamentos ligados a práticas sexuais ilícitas e outras situações ligadas à sensualidade pecaminosa" (:36)..$^{12}$ Mas o impacto maior decorre da reprodução fotográfica de inúmeras cenas de rituais secretos de iniciação, como o orô (momento do sacrifício do animal sobre a cabeça do iniciado). Essas cenas são, de fato, o "calcanhar de Aquiles" dos cultos afros, sobretudo quando retiradas de seu contexto, visando criar a imagem dessas religiões como "sangrentas", "selvagens" ou "primitivas". As fotos de um sacrifício animal feito sobre a cabeça de uma iniciada e de fiéis ajoelhados diante de um congá (altar) apresentam as seguintes legendas: "A feitura da cabeça! Nesse estágio o adepto já fez um pacto com os demônios. Só Jesus poderá libertá-lo" (Macedo 1996:77); "Festa de formatura, onde os adeptos 'ganham de presente' uma legião de demônios para trabalhar com eles" (:65). 
No entanto, a "evidência" maior da ação do demônio estaria, segundo o livro, nos assassinatos de pessoas em rituais afro-brasileiros, noticiados pela impressa e cujas manchetes estão reproduzidas no livro: "Mataram moça pra fazer despacho" (:46); "A polícia encontrou no local do despacho, cérebro e outros órgãos humanos, entre eles, um coração" (:56); "Bebê vítima de satanismo" (:109); "Homem morto à faca em ritual de umbanda" (:109). Obviamente que esses fatos, embora tenham ocorrido como atestam as reportagens, não constituem práticas características dos sistemas religiosos afro-brasileiros. Entretanto, seu autor está convencido de que as religiões afro-brasileiras estão por trás de todas essas manifestações, daí colocar fotos de pessoas assassinadas como animais em rituais (tendo o corpo coberto por sangue) e de pessoas deitadas em um quarto de iniciação (tendo sobre o corpo o sangue ritual dos animais). A seqüência de imagens parece querer exprimir uma lógica na qual se prescreve que onde se mata o animal sobre o humano pode-se matar o humano como se fosse animal. ${ }^{13}$

Também as legendas das fotos de crianças participando dos rituais reforçam o estereótipo negativo sobre a religião: “Essas crianças, por terem sido envolvidas com os orixás, certamente não terão boas notas na escola e serão filhos 'problemas' na adolescência" (:50).

As referências às religiões afro-brasileiras existentes em espaços públicos também demonstrariam, segundo o livro, a expansão da ação do demônio para além dos muros dos terreiros. Sob a foto da estátua de Iemanjá, localizada no litoral paulista, lê-se: “Iemanjá, na Umbanda, é a mesma Virgem Maria da religião católica. Muitos outros 'santos' são associados aos demônios" (:53). Fotos de placas de casas comerciais com os nomes de orixás (Gráfica Oxum, Restaurante Xangô etc.) ou esculturas de orixás, muito comuns em Salvador, também são alvos de críticas $(: 80,153)$.

Na trilha aberta por Mãe-de-santo, além de Orixás, caboclos \& guias. Deuses ou demônios?, muitos outros livros têm sido escritos delimitando uma área de interesse crescente na literatura de divulgação religiosa dos pastores neopentecostais. É o caso do livro Espiritismo, a magia do engano, cujo autor, o missionário Romildo Ribeiro Soares (ou R.R. Soares), depois de romper com Edir Macedo, fundou em 1980 a Igreja Internacional da Graça de Deus. Do púlpito desta igreja também vem convocando os fiéis para combaterem os "demônios afro-brasileiros" sem, contudo, ameaçar o protagonismo que marca a atuação de Macedo nesse campo. ${ }^{14}$ Esta literatura tem, inclusive, se diversificado e estende seu foco de ataque para outras religiões consideradas "heresias" ou "seitas"15.

Se os livros citados nos permitem uma introdução ao universo da literatura de divulgação que fundamenta a "teologia da batalha espiritual"16, 
é sobretudo no plano dos atos rituais que sua mensagem tem gerado maior eficácia e adquirido grande visibilidade, tanto no interior das igrejas pentecostais como em outros espaços. Vejamos a seguir alguns exemplos da ação neopentecostal contra a presença do diabo associada às religiões afro-brasileiras.

\section{0 "demônio" na prática}

Para que possamos entender melhor a natureza e a extensão dos casos de ataques neopentecostais ${ }^{17}$ às religiões afro-brasileiras, recolhi informações sobre eles publicadas na imprensa escrita e na literatura acadêmica dos últimos anos e classifiquei-os segundo alguns critérios: 1. Ataques feitos no âmbito dos cultos das igrejas neopentecostais e em seus meios de divulgação e proselitismo; 2. Agressões físicas in loco contra terreiros e seus membros; 3 . Ataques às cerimônias religiosas afro-brasileiras realizadas em locais públicos ou aos símbolos destas religiões existentes em tais espaços; 4 . Ataques a outros símbolos da herança africana no Brasil que tenham alguma relação com as religiões afro-brasileiras; 5 . Ataques decorrentes das alianças entre igrejas e políticos evangélicos e, finalmente, 6 . As reações públicas (políticas e judiciais) dos adeptos das religiões afro-brasileiras. Vejamos alguns casos representativos de cada grupo.

1. Como vimos acima, os ataques feitos no âmbito das práticas rituais das igrejas neopentecostais e de seus meios de divulgação e proselitismo têm como ponto de partida uma teologia assentada na idéia de que a causa de grande parte dos males deste mundo pode ser atribuída à presença do demônio, que geralmente é associado aos deuses de outras denominações religiosas. Caberia aos fiéis, segundo esta visão, dar prosseguimento à obra de combate a esses demônios iniciada por Jesus Cristo: "Para isto se manifestou o Filho de Deus: para destruir as obras do diabo" (1 João 3:8). O panteão afro-brasileiro é especialmente alvo deste ataque, sobretudo a linha ou a categoria de exu, que foi associada inicialmente ao diabo cristão e posteriormente aceita nessa condição por uma boa parcela do povo-desanto, principalmente o da umbanda.

No interior das igrejas neopentecostais são freqüentes as sessões de exorcismo (ou "descarrego", conforme denominação da Igreja Universal do Reino de Deus - IURD) dessas entidades, que são chamadas a incorporar para em seguida serem desqualificadas e expulsas como forma de libertação espiritual do fiel. Dos púlpitos, este ataque estende-se aos programas religiosos (Fala que eu te escuto, Ponto de luz, Pare de sofrer, Show da fé 
etc.) transmitidos pela Rede Record (de propriedade da IURD) e por outras emissoras que têm seus horários comprados pelas igrejas neopentecostais. Em muitos desses programas são exibidas "reconstituições de casos reais" ou dramatizações, nas quais símbolos e elementos das religiões afro-brasileiras são retratados como meios espirituais para a obtenção unicamente de malefícios: morte de inimigos, disseminação de doenças, separação de casais ou amarração amorosa, desavença na família etc. São comuns nesses programas os testemunhos de conversão dados por pessoas que se apresentam como antigos freqüentadores de terreiros, são entrevistados pelo pastor e "confessam" os malefícios que teriam sido feitos com a ajuda das entidades afro-brasileiras (chamadas de "encostos"). Os testemunhos mais explorados são os dos que se apresentam como ex-sacerdotes das religiões afro-brasileiras, chamados de "ex-pais-de-encosto", que explicam detalhadamente como faziam os despachos e sua intenção malévola.

A vasta rede de comunicação dessas igrejas inclui ainda programas de rádio, sites na Internet e material de divulgação religiosa (livros, jornais, revistas e folhetos), como a Folha Universal e a revista Plenitude, ambas da IURD. Os livros best-sellers já mencionados, Orixás, caboclos e guias. Deuses ou demônios e Espiritismo. A magia do engano, são os mais conhecidos.

2. Insuflados por essa crença, os membros das igrejas neopentecostais muitas vezes invadem terreiros visando destruir altares, quebrar imagens e "exorcizar" seus freqüentadores, o que geralmente termina em agressão física. No Rio de Janeiro, umbandistas do Centro Espírita Irmãos Frei da Luz foram agredidos com pedradas pelos freqüentadores de uma IURD situada ao lado deste Centro, na Abolição. ${ }^{18}$ Uma adepta da Tenda Espírita Antônio de Angola, no bairro do Irajá, foi mantida, por dois dias, em cárcere privado em uma igreja evangélica em Duque de Caxias, com o objetivo de renunciar à sua crença e converter-se ao evangelismo. ${ }^{19}$

Em Salvador, tida como a "capital da macumbaria" ou a "Sodoma e Gomorra da magia negra" pelos neopentecostais, uma iniciada no candomblé teve sua casa, no bairro de Tancredo Neves, invadida por 30 adeptos da Igreja Internacional da Graça de Deus, que jogaram sal grosso e enxofre na direção das pessoas ali reunidas durante uma cerimônia religiosa. ${ }^{20}$ Estas substâncias materiais também são atiradas em automóveis que possuem colar de contas (guia) pendurado no espelho retrovisor. ${ }^{21}$

Em São Luís, capital maranhense, alguns fiéis da Assembléia de Deus residentes no bairro acusaram os chefes do Terreiro do Justino, localizado na Vila Embratel, de seqüestro de um bebê, filho de um casal de freqüentadores desta igreja que residia na vizinhança. Acreditavam que o bebê teria sido raptado para ser sacrificado nos ritos do terreiro..$^{22}$ Acionaram a polícia que, 
mesmo sem uma ordem judicial, revistou as instalações do templo, incluindo os quartos sagrados interditados aos não-iniciados. Até a geladeira da casa e os carros estacionados no quintal foram alvos da busca policial. A investigação só não foi levada adiante porque os reais seqüestradores da criança foram capturados. O terreiro, fundado há 104 anos, é um dos mais antigos da cidade e vem sofrendo pressões por parte dos evangélicos do bairro para que seja transferido dali. ${ }^{23}$ Esta é, aliás, uma estratégia dos pastores que, ao se instalarem nos bairros, identificam os terreiros da região e estabelecem prazos para fechá-los. ${ }^{24}$

No bairro Engenho Velho da Federação, em Salvador, onde existem cerca de 19 terreiros de candomblé (famosos por sua tradição, como a Casa Branca e o Gantois), o confronto vem se acirrando. Para demonstrar sua força, as igrejas evangélicas organizaram uma passeata para intimidar os seguidores dos "demônios" naquele bairro. Em resposta, o povo-de-santo saiu às ruas vestindo roupas brancas, cor associada à paz e a Oxalá, o orixá da criação, segundo o candomblé. ${ }^{25}$ Outra manifestação deste tipo de ataque é dificultar, utilizando vários meios, a realização das atividades rituais dos terreiros. Uma mãe-de-santo da Cidade Tiradentes, em São Paulo, reclamou de um carro de som, contratado por uma igreja neopentecostal das imediações, que parava ou circulava insistentemente em frente ao seu terreiro para anunciar em alto volume as "sessões de descarrego" realizadas na referida igreja. ${ }^{26}$

3. Quando as atividades religiosas (festas de orixá, oferendas, procissões etc.) são feitas em lugares públicos (praias, matas, cachoeiras, ruas, largos e ginásios), os adeptos ficam mais expostos a esses ataques, que englobam desde a simples distribuição aos presentes de panfletos com propaganda contra esses cultos até a tentativa de interrupção forçada dos rituais. Durante uma festa de Iemanjá ocorrida na praia do Leme, Rio de Janeiro, neopentecostais pregaram contra esta cerimônia com o auxílio de alto-falantes e destruíram os presentes ofertados a esta entidade associada ao mar. O mesmo ocorreu durante uma festa de erês (entidades infantis) realizada na Quinta da Boa Vista, quando os neopentecostais quebraram imagens e queimaram roupas de santo. ${ }^{27}$

Símbolos das religiões afro-brasileiras colocados em espaços públicos também podem ser atacados. A revitalização do Dique do Tororó, que incluiu a instalação de esculturas dos orixás pela prefeitura de Salvador, rendeu uma série de críticas das igrejas evangélicas que condenaram esse ato de "enaltecimento de uma religião diabólica", "associada ao mal", que precisaria ser "exorcizada", segundo esta ótica, e não homenageada pelo poder público. Este último, argumentando que as imagens dos orixás, mais do que símbolos religiosos específicos, fazem parte da cultura baiana, assim 
justificou sua ação. De fato, esculturas e imagens retratando deuses afrobrasileiros estão dispersas em muitos outros locais da capital baiana, como ruas, praças e edifícios, sendo seus nomes usados, inclusive oficialmente, para identificar alguns desses locais e estabelecimentos comerciais e culturais. Há, entretanto, uma forte oposição a isto. A diretora de uma escola, no bairro de Stella Maris, teve de mandar apagar a figura do orixá Ogum, que havia em um painel artístico situado naquele edifício escolar, por pressão dos pais evangélicos cujos filhos estudavam ali. ${ }^{28}$

Em São Paulo, agressões à estátua de Iemanjá, na Praia Grande, como tentativa de depredação, também têm sido registradas (Mariano 1999:123). A intolerância religiosa pode manifestar-se no compartilhamento de locais ou transportes públicos, como no caso de uma mulher que por trajar um turbante branco, típico dessas religiões, foi expulsa do ônibus em que viajava na zona norte da cidade carioca. ${ }^{29}$

4. Símbolos da herança africana no Brasil, mesmo que não sejam exatamente religiosos, mas de alguma forma aludam às religiões afro-brasileiras, são estigmatizados e combatidos. No Rio de Janeiro, por influência das igrejas neopentecostais, houve um esvaziamento da bateria mirim da "Toca o Bonde - Usina de Gente", uma organização não-governamental que ensina música às crianças e aos jovens carentes moradores em algumas comunidades da região de Santa Teresa. Os pais evangélicos retiraram seus filhos dessa ONG, alegando que o samba está vinculado ao "culto do demônio". Nessa ótica, escola de samba é, portanto, "escola do capeta"30.

Uma outra face da desqualificação desses símbolos é, paradoxalmente, a sua "incorporação" nas práticas evangélicas, porém dissociando-os de sua relação com as religiões afro-brasileiras. Assim, surge a capoeira de Cristo, evangélica ou gospel, em cujas letras não há referências aos orixás ou aos santos católicos. O $1^{\circ}$. Encontro Nacional de Capoeiristas Evangélicos aconteceu em 2005, em Goiânia, e o tema escolhido foi "Deus — o verdadeiro ancestral da capoeira" ${ }^{\prime 11}$. Neste contexto, há uma refutação da contribuição da ancestralidade ou da espiritualidade africana na formação da capoeira, como se vê na menção a "Deus" como o "verdadeiro ancestral" dessa prática que, na sua origem, esteve intimamente relacionada ao candomblé. Outro exemplo é o "acarajé do Senhor" feito por mulheres evangélicas que querem dissociar este alimento das religiões afro-brasileiras (o acarajé é uma comida votiva de Iansã) e da imagem das baianas que tradicionalmente o comercializam vestidas com suas saias brancas e seus colares de conta (guias) - uma indumentária típica dos terreiros e conhecida nacionalmente.

Com a recente decisão do Ministério da Educação pela inclusão da temática "História e Cultura Afro-brasileira" no currículo oficial da rede de 
ensino ${ }^{32}$, livros didáticos abordando este assunto começam a ser produzidos. Como as religiões afro-brasileiras são parte desta história e desta cultura, suas características têm sido tratadas de forma não-sectária ou proselitista, como convém a um material destinado ao ensino laico, humanista e de difusão da tolerância à diversidade cultural. Entretanto, colocar nos livros escolares as religiões de origem africana ao lado de religiões hegemônicas, como o cristianismo, dando-lhes o mesmo espaço e legitimidade destas últimas, tem gerado, por si só, protestos. Foi o que ocorreu com uma coleção de livros didáticos destinada ao Ensino Fundamental, lançada por uma editora de São Paulo. No volume indicado para a $2^{\text {a }}$. série, no capítulo "Nossas raízes africanas", a autora trata da formação das religiões afro-brasileiras, inclusive com exercícios que objetivam que as crianças pesquisem sobre a história dos orixás. Uma coordenadora pedagógica evangélica de Belfort Roxo, Rio de Janeiro, protestou junto à editora, alegando que o livro fazia apologia das religiões afro-brasileiras e que não seria adotado em sua escola, onde a maioria dos alunos e professores, segundo ela, era evangélica. A mesma coleção também gerou protesto na Câmara da cidade de Pato Branco, Paraná, onde um vereador também pastor evangélico denominou a obra de "livro do demônio" e pediu a cassação da coleção. ${ }^{33}$ Vale lembrar que o referido material didático foi avaliado e obteve parecer muito favorável, sendo recomendado pelo Guia do Plano Nacional do Livro Didático (PNLD-2004). ${ }^{34}$

5. Como se vê neste último caso, com a crescente eleição de candidatos evangélicos ou de aliados dessas igrejas, a batalha contra outras denominações religiosas se reflete ou se ampara no campo da representação política. Políticos evangélicos, aproveitando-se do poder decorrente deste campo, vêm articulando ações antagônicas ao desenvolvimento das religiões afro-brasileiras. No Rio Grande do Sul, por pressão desses políticos e com o apoio das sociedades protetoras dos animais, o Código Estadual de Proteção aos Animais tem sido acionado na tentativa de coibir os sacrifícios rituais do candomblé. Um parágrafo específico deste Código, que não foi aprovado por pressão dos religiosos afro-brasileiros, vetava a realização de cerimônia religiosa que envolvesse a morte de animais. ${ }^{35}$ Mesmo assim, baseadas na interpretação deste Código, têm sido possíveis ações judiciais contra sacerdotes afro-brasileiros, como ocorreu com a mãe-de-santo Gissele Maria Monteiro da Silva, de Rio Grande, condenada a 30 dias de prisão por realizar sacrifícios de animais em seu terreiro. ${ }^{36}$

6. Diante desses ataques, as reações dos religiosos afro-brasileiros e de seus aliados, que eram quase insignificantes há duas décadas, têm crescido, mas ainda estão muito longe de representar um movimento articulado que faça frente à organização dos evangélicos, que cada vez mais se empenham 
em ocupar espaços estratégicos nos meios de comunicação e nos poderes Legislativo e Executivo. Inicialmente, essa reação se fez na forma de protestos, como o do deputado estadual e umbandista Átila Nunes que, em 1981, solicitou ao então ministro da justiça Ibrahim Abi Ackel providências sobre o tema. ${ }^{37}$ No final dessa mesma década, Edir Macedo foi processado pelo Conselho Nacional Deliberativo da Umbanda e dos Cultos Afro-brasileiros por vilipêndio a culto religioso, calúnia e difamação, o que ocasionou uma breve contenção na intensidade dos ataques nesse período. ${ }^{38}$

A trégua durou pouco, pois em meados dos anos de 1990, a agressão a uma imagem de Nossa Senhora Aparecida, feita por um bispo da IURD durante um programa televisivo - fato que ficou conhecido como o "Chute na Santa" - motivou a reação de vários segmentos da sociedade brasileira, colocando essa igreja neopentecostal em uma situação difícil. ${ }^{39}$ Este episódio foi duplamente exemplar. Primeiro, mostrou que quando os ataques da IURD dirigem-se diretamente aos símbolos de uma religião majoritária e hegemônica, como o catolicismo, sua eficácia é reduzida. O que não ocorre com os ataques às religiões afro-brasileiras que, em geral, têm se mostrado eficazes tanto na conversão de adeptos, como no comprometimento da imagem pública desta religiosidade. Segundo, mostrou aos adeptos afrobrasileiros a necessidade de reagirem de forma cada vez mais organizada para tentarem preservar a relativa aceitação e legitimidade conquistadas a duras penas perante a sociedade.

Assim, nos últimos anos, alguns movimentos de defesa das religiões afro-brasileiras têm sido criados e, no âmbito jurídico, ações legais têm sido impetradas pelos babalorixás e ialorixás contra pastores e/ ou suas igrejas. A Bahia é o estado onde existe atualmente um número maior de casos registrados de reação. Segundo levantamentos publicados por um jornal ${ }^{40}$, nos últimos sete anos foram registrados quase 200 reclamações e processos, os quais englobam, entre outras, ações por difamação contra sacerdotes evangélicos e seus seguidores (e também contra alguns padres) por afirmarem publicamente serem as religiões afro-brasileiras demoníacas, distribuírem folhetos com este conteúdo (geralmente em festas públicas de orixás), apresentarem programas na televisão vilipendiando símbolos dessas religiões ou atacarem terreiros e seus membros.

Nesses processos, o Ministério Público tem tido uma atuação importante, embora a lentidão das varas judiciais criminais, para as quais os processos são enviados, desestimule uma ação sistemática por parte das vítimas. Além disso, elas não possuem, em geral, conhecimento suficiente dos mecanismos de funcionamento do poder judiciário para neles atuarem de forma mais incisiva. Ao considerarem essas dificuldades e na tentativa de 
criarem fóruns de debate e rotinas mais ágeis para o encaminhamento dos processos, entidades de defesa dos direitos civis estão propondo a criação de uma vara específica para os casos de discriminação racial e religiosa. ${ }^{41}$

Apesar das dificuldades, essas ações jurídicas começam a dar resultados favoráveis aos adeptos das religiões afro-brasileiras. As igrejas evangélicas responsáveis pelos programas, considerados ofensivos às religiões afro-brasileiras, e as redes de televisão que os exibem estão sendo notificadas. Na Bahia, há inúmeros processos em andamento, alguns deles com sentenças outorgadas. ${ }^{42}$ O programa Ponto de Luz, da Igreja Universal de Deus, teve seu horário de exibição alterado (reclassificação etária), ficando proibidas as referências pejorativas às religiões afro-brasileiras..$^{43}$ Em São Paulo, as redes de televisão (Record, Rede Mulher e outras) que apresentam programas ofensivos (Sessão Descarrego, Mistérios etc.) foram condenadas a exibir em sua programação o direito de resposta dos representantes das religiões afro-brasileiras. ${ }^{44}$

O caso mais emblemático de reação é o de mãe Gilda (Gildásia dos Santos e Santos), do Axé Abassá de Ogum, em Itapuã, Bahia, que em 1992 participou em Brasília de um protesto contra o governo Collor, tendo sido fotografada pela revista Veja ao lado de um despacho. ${ }^{45}$ Posteriormente, essa imagem foi usada em uma edição de 1999 da Folha Universal ${ }^{46}$ (publicação da IURD) ao lado da manchete "Macumbeiros charlatões lesam a bolsa e a vida dos clientes - O mercado da enganação cresce no Brasil, mas o Procon está de olho". Este fato e a invasão de seu terreiro por membros da Igreja Deus é Amor que tentaram "exorcizá-la" levaram a mãe-de-santo a decidir pela ação judicial contra seus agressores e difamadores. Mãe Gilda faleceu em seguida, aos 65 anos, de um infarto fulminante, em conseqüência, segundo sua família, desses acontecimentos que a abalaram profundamente. ${ }^{47}$ Em 2004, a Justiça condenou a Igreja Universal e sua gráfica a indenizar a família da ialorixá em R $\$ 1.372 .000$ pelo uso indevido de sua imagem ( $\mathrm{R} \$ 1,00$ para cada exemplar do jornal publicado com a matéria)..$^{48} \mathrm{O}$ caráter emblemático deste caso levou nesse mesmo ano a Câmara de Vereadores de Salvador a transformar a data de falecimento da ialorixá, 21/1/2000, em "Dia Municipal de Combate à Intolerância Religiosa".

O livro Orixás, caboclos e guias. Deuses ou demônios? é outra publicação que vem sendo questionada na Justiça. Na Bahia, a Procuradoria Estadual enviou à Procuradoria da República um pedido para retirar de circulação o livro por considerar seu caráter ofensivo às religiões afro-brasileiras..$^{49}$ No Rio de Janeiro, a Justiça condenou em 2004 a IURD e a Editora Gráfica Universal, responsável pela publicação do livro, a pagar R $\$ 120.000$ pelo uso indevido da imagem do adolescente Ricardo Navarro que aparece em uma foto, na época com 4 anos de idade, tocando atabaque no terreiro de sua avó, 
a ialorixá Palmira de Iansã, em Mesquita. Segundo a legenda da foto: "Essas crianças, por terem sido envolvidas com os orixás, certamente não terão boas notas na escola e serão filhos 'problemas' na adolescência". A ialorixá já havia processado a Editora há dez anos pelo uso da imagem de três crianças em seu terreiro, que aparece no livro e no Jornal Folha Universal para ilustrar uma matéria intitulada "Filhos do demônio". A gráfica foi condenada a pagar 20 salários mínimos para as famílias das três crianças. Uma destas crianças, hoje adolescente, lembra que na época foi alvo de chacota na escola: "Eu fui chamada de macumbeira, que vivia em religião de demônio"50.

O povo-de-santo, percebendo a necessidade de se contrapor aos ataques neopentecostais e de se defender deles, tem procurado articular-se e superar as divergências existentes entre as várias denominações religiosas (candomblé e umbanda, por exemplo) e entre os diferentes modelos de culto que há no seu interior (candomblé queto e angola, entre outros). Historicamente, essas religiões desenvolveram-se muito mais por dissidências ou contraposições do que por aglutinação em torno de entidades de representação coletiva. O modelo de organização federativa dos centros espíritas, por exemplo, foi adotado com relativo sucesso pelos terreiros de umbanda, mas pouca influência teve entre os de candomblé. Mesmo assim, algumas entidades federativas têm procurado encaminhar posições e estabelecer interlocução com outros agentes do poder público, do movimento negro, das organizações não-governamentais etc.

Na Bahia, o Movimento Contra a Intolerância Religiosa, iniciado em 2000, teve como articuladores vários desses agentes, como a Federação Baiana de Culto Afro, o Centro de Estudos Afro-Orientais (da Universidade Federal da Bahia), o Programa Egbé - Territórios Negros (desenvolvido pela Koinonia - Presença Ecumênica e Serviço), e vem aglutinando outras instituições afins. Em São Paulo, o Instituto da Tradição e Cultura Afro-brasileira (Intecab) e a Comissão de Assuntos Religiosos Afrodescendentes também buscam articular a comunidade religiosa, organizando passeatas e atos de protesto contra a discriminação religiosa e alertando sobre a necessidade de eleger políticos afinados com os interesses das religiões afro-brasileiras. ${ }^{51}$

O Superior Órgão de Umbanda do Estado de São Paulo e a União das Tendas de Umbanda e Candomblé do Brasil vêm atuando por meio de processos judiciais contra pastores evangélicos. ${ }^{52}$ No Rio Grande do Sul, a Comissão de Defesa das Religiões Afro-Brasileiras (CDRAB), estruturada em 2002, e as federações de cultos da capital gaúcha organizam-se tanto para eleger candidatos da comunidade religiosa, como para reagir à ação de políticos evangélicos, como no caso citado acima de tentativa de proibição de sacrifícios de animais nos terreiros. 
Outra estratégia de resistência dos afro-brasileiros tem sido a de buscar apoio no movimento ecumênico, considerando que o ataque neopentecostal também se dirige a outras religiões, principalmente ao catolicismo. Além do já comentado episódio do "chute na santa", manifestações públicas de fé católica são alvo de ataques, como os tumultos provocados por fiéis neopentecostais durante as procissões católicas, como a do Senhor Morto, na Sexta-feira da Paixão ${ }^{53}$, ou nas romarias populares, como a de Padre Cícero, em Juazeiro do Norte. ${ }^{54}$ Sem contar que o próprio papa é visto como "o representante do demônio na terra" e padres e bispos geralmente são apontados como praticantes de pedofilia e homoerotismo (Mariano 1999:124). Por meio desse movimento ecumênico, os cultos afro-brasileiros podem encontrar a solidariedade de igrejas evangélicas que discordam e condenam os ataques realizados pelas denominações neopentecostais mais intolerantes. ${ }^{55}$

Enfim, o desenvolvimento das religiões afro-brasileiras foi marcado pela necessidade de se criarem estratégias de sobrevivência e diálogo diante das condições adversas. Essas religiões foram perseguidas pela igreja católica ao longo de quatro séculos; pelo Estado republicano, sobretudo na primeira metade do século XX, quando este se valeu de órgãos de repressão policial e de serviços de controle social e higiene mental; finalmente, pelas elites sociais, em um misto de desprezo e fascínio pelo exotismo que sempre esteve associado às manifestações culturais dos africanos e seus descendentes no Brasil.

Entretanto, desde pelo menos a década de 1960, quando essas religiões conquistaram relativa legitimidade nos centros urbanos, resultado dos movimentos de renovação cultural e de conscientização política, da aliança com membros da classe média, acadêmicos e artistas, entre outros fatores, não se tinha notícia da formação de agentes antagônicos tão empenhados na tentativa de sua desqualificação. Portanto, ainda que incipiente, a união de religiosos afro-brasileiros, movimento negro, ONGs, acadêmicos, pesquisadores, políticos, advogados, promotores públicos, entre outros, parece apostar mais uma vez na capacidade de resistência e reação dessas religiões contra um assédio proporcionalmente muito mais eficaz e, a julgar por seu estado atual e crescimento numérico, duradouro. Outra questão que esses antagonismos indicam refere-se às possíveis mudanças de certo imaginário construído sobre o Brasil, no qual as religiões afro-brasileiras aparecem associadas a um "jeito de ser brasileiro" (em figuras como o malandro, representado por Exu, ou a "mulher faceira e sensual", representada pela Pombagira), cujo epíteto é o do tão afamado "jeitinho" que misturaria as esferas do público e do privado, do "favor" e do direito. Vejamos de que forma o neopentecostalismo parece colocar novos desdobramentos para essa interpretação do imaginário brasileiro. 


\section{Nem malandro, nem caxias - o "favor" e o "direito" como mediadores}

No artigo "Duas respostas à aflição: umbanda e pentecostalismo", Peter Fry e Gare Howe (1975) se perguntavam como era possível a coexistência desses dois movimentos religiosos, que diferem tão profundamente em termos de organização e cosmologia, entre um público de mesmo perfil sociológico (trabalhadores e imigrantes urbanos). Concluíram que ambos representavam duas maneiras distintas e opostas de interpretar e lidar com as aflições da sociedade brasileira. O pentecostalismo, descendente do metodismo wesleyano, estaria mais relacionado com o mundo da ordem, (ou do caxias, para usar a dicotomia proposta por Roberto DaMatta 1979), no qual a renúncia aos divertimentos e aos prazeres do corpo (bebidas, sexo etc.), em prol de uma moral rigorosa, criava uma nítida separação entre crentes e não-crentes. O mundo de Cristo não se confundia com o mundo do Diabo, sendo o culto aos "espíritos das trevas", atribuído à umbanda, a principal crítica dos pentecostais a esta religião. Ou seja, o primeiro movimento encontraria na ordem ascética imposta pelo sistema de crenças uma forma de lidar com a desordem e a desigualdade da vida social. O segundo, sem negar essa desordem, buscaria seus mediadores na tentativa de superá-la com base na manipulação mágica em proveito próprio.

De um lado (umbanda) temos a idéia do mundo como algo manipulável, o mundo do "galho quebrado" e do malandro (DaMatta 1973), onde o indivíduo negocia um caminho pela vida na base de manipulações pessoais de recursos sociais. De outro lado (pentecostalismo) achamos um mundo percebido como essencialmente "racional", no sentido weberiano (Fry e Howe 1975:82).

Para Peter Fry, em trabalho posterior, no qual compara a umbanda em São Paulo com o metodismo praticado em Manchester no século XIX, o termo "despacho" e seus derivados, usados tanto no contexto umbandista como no da burocracia oficial, permitem entender a forma pela qual a experiência social de grupos destituídos do direito legítimo de acesso ao Estado se reflete no plano do imaginário religioso: "Os despachantes e os políticos locais fazem a mediação entre Estado e o homem comum, assim como os espíritos da umbanda mediam sua relação com um Deus distante e desinteressado". Por isso, os "espíritos das trevas" (principalmente Exu), a quem se pede o favor por meio do despacho, seriam tão fundamentais nesse sistema como os "espíritos de luz": "Exu da meia-noite/ Exu da encruzilhada/ O povo da umbanda/ Sem Exu não consegue nada" (Fry 1982:40). 
A novidade que vem transformando este cenário, desde que foi analisado há 30 anos por estes autores, é o desenvolvimento do neopentecostalismo que ao se distanciar do pentecostalismo clássico e ao se aproximar da umbanda e de outras religiões afro-brasileiras, ainda que seja para negá-las, passou a traduzir para seu próprio sistema o ethos da manipulação mágica e pessoal, mas agora sob nova direção, colocando o "direito" no lugar do "favor". A base sociológica comum entre pentecostais e umbandistas, que propiciava a "dupla resposta à aflição" — opostas e distintas — conforme apontada por Fry e Howe, muito provavelmente tenha possibilitado o surgimento desta "terceira resposta à aflição", que se apropria a seu modo das duas anteriores. Ou seja, o neopentecostalismo, ao "abrandar" o ascetismo, suavizando o estereótipo do "crente" do protestantismo histórico, passou a valorizar os prazeres terrenos e a estimular o consumo de bens materiais como sinais da salvação.

Ao abrir-se para o mundo, para a sociedade de consumo (incluindo o "consumo do corpo"), promoveu uma intermediação importante entre o ethos religioso do pentecostalismo tradicional e o das concepções afro-brasileiras, marcadas historicamente por sua abertura para o mundo (nas quais o sagrado assume a feição do mundano e não o contrário). Sintomaticamente, essa aproximação elegeu a figura de Exu (ou dos "espíritos das trevas"), invocado originariamente nas sessões umbandistas e agora nas sessões neopentecostais de exorcismo ou de descarrego, como seu elemento de mediação e inversão. Ao contrário da invocação umbandista, no neopentecostalismo Exu não é mais chamado para atuar como mensageiro ou "sujeito do favor". Agora, sua função é vir para ser expulso em nome da cura e da salvação do possuído. Não sendo mais a morada do maligno, o liberto "expulsa o favor" (que no sistema da umbanda sempre o deixava à mercê dos despachos) e impõe seu "direito" à graça divina, falando diretamente ao seu detentor celestial por excelência. Na literatura religiosa neopentecostal, proliferam títulos que aludem à necessidade do fiel se colocar como alguém que "exige seus direitos", que "toma posse da benção"56. Nesse sentido, ao mesmo tempo em que combatem o "feitiço", não descartam a magia implícita em suas liturgias que se aproveitam do léxico e dos elementos simbólicos das religiões afro-brasileiras. ${ }^{57}$

Os ritos de expulsão do demônio e cura (e muitos outros) representam, ainda, o retorno ao ritual mágico como uma dimensão crucial da prática da fé e dos mecanismos de salvação ou obtenção da graça. Essa dimensão, que havia sido expulsa do metodismo, reaparece de certa forma no pentecostalismo (com o reavivamento do sagrado no transe do Espírito Santo), mas é reintroduzida em grande escala somente no neopentecostalismo, aproxi- 
mando este segmento das religiões afro-brasileiras, que têm na rotinização dos ritos um de seus elementos estruturantes (Silva 1995). Entretanto, como o uso de um léxico só faz sentido no interior de uma comunidade que compartilha seus significados ou, nos termos levistraussianos, quando "enfeitiçado", "feiticeiro" e "grupo" compartilham os significados dos símbolos usados, a introdução de certos ritos exige o conhecimento de seu léxico e gramática. O neopentecostalismo, ao disseminar essa gramática (na forma de livros, programas televisivos, "entrevistas com o demônio" etc.), acaba por torná-la eficaz nos seus ritos de cura e libertação. Como apontam Fry e Howe (1975:90):

[...] podemos deduzir que há uma maior probabilidade de cura "milagrosa" onde os símbolos empregados têm significado para o paciente. Poderíamos então argumentar que um motivo poderoso para um indivíduo afiliar-se a uma associação religiosa poderia depender de quão significativos são a crença e o ritual.

Livros como Mãe-de-santo e Orixás, caboclos e guias, entre muitos outros, parecem mesmo "manuais de feitiçaria" que primeiro apresentam com detalhes os sistemas religiosos afro-brasileiros e espíritas, com informações extraídas preferencialmente de seus ex-participantes, e depois os condenam com base na bíblia, finalmente ensinando ao leitor convertido distanciarse desses sistemas com a ajuda dos pastores e seus ritos. As freqüentes sessões de exorcismos contribuem enormemente para esse aprendizado, pois articulam tais sistemas de crenças. O próprio Edir Macedo (1996:121) reconhece que

Se alguém chegar à igreja no momento em que as pessoas estão sendo libertas, poderá até pensar que está em um centro de macumba, e parece mesmo [...] Alguém poderá pensar: "Como podem baixar esses espíritos em uma igreja, uma Casa de Deus?". É importante, antes de mais nada, termos ciência de que as pessoas nas quais se manifestam os espíritos infernais não os encontraram na igreja: estavam dentro delas.

Para que tais espíritos entrem no corpo das pessoas como exus e saiam como demônios, é preciso uma operação em que os dois sistemas de referência (neopentecostal e afro-brasileiro) se sobreponham e forneçam previamente seus significados, um a serviço da eficácia simbólica do outro. Caso contrário, não somente é impossível responder se os orixás, os caboclos e os guias são deuses ou demônios, como a própria pergunta não faz sentido. Antes que os termos sejam trocados de lugar de um sistema para outro, é 
preciso estabelecer equivalências entre eles a partir dos lugares que ocupam em seus próprios sistemas e nos sistemas que os recebem. ${ }^{58}$

Enfim, as igrejas neopentecostais ao combaterem os terreiros afro-brasileiros - em nome da evangelização e da libertação espiritual — promovem um afastamento entre esses dois campos religiosos. Tal afastamento estimula o crescimento dessas igrejas em função da evasão de adeptos e de clientes dos terreiros e da degeneração da imagem pública destes últimos. Há, porém, em sentido inverso, um entrelaçamento destes campos que os aproxima, como tem sido demonstrado por alguns estudiosos do tema.

Esta afirmação torna-se consistente ao observarmos que a produção literária, as concepções religiosas, o uso da oralidade e do transe, as cosmogonias, os ritos e as liturgias que constituem a teologia neopentecostal fornecem uma "pedagogia" em que se aproveita o léxico e a gramática do sistema detratado em seu próprio benefício. Valer-se da lógica mágico-religiosa do outro é o primeiro passo para tentar garantir a operacionalidade desta lógica quando aplicada em seu próprio sistema, a partir de outros pressupostos. A "inversão", também sendo uma "versão", só faz sentido quando se conhece o que se inverte. No limite, porém, ambas, versões e inversões, dependem umas das outras para ampliar seus significados e afirmar suas identidades por contraste.

Recebido em 10 de julho de 2006

Aprovado em 22 de janeiro de 2007

Vagner Gonçalves da Silva é professor do Departamento de Antropologia da USP. E-mail: <vagnergo@usp.br>

\section{Notas}

* Versões preliminares deste texto foram apresentadas na Jornada de Direitos Humanos (Associação Brasileira de Antropologia - ABA e Universidade São Judas Tadeu), no VII Congresso da Associação de Estudos Brasileiros (BRASA) e na XXIV Reunião da Associação Brasileira de Antropologia, eventos ocorridos em 2003, e nos Seminários: "O campo das religiões no Brasil: continuidades e rupturas" (ISER/ Assessoria) e "Raça, Racismo e Políticas Públicas: um debate antropológico" (ABAUFBA), ocorridos em 2004. Gostaria de agradecer aos interlocutores nessas ocasiões 
e aos leitores da versão final deste artigo pelas críticas e sugestões recebidas, especialmente a Rita Amaral.

${ }^{1}$ É recorrente entre os autores consultados a divisão do movimento pentecostal em três ondas, fases ou momentos históricos, em uma classificação ora cronológica-institucional em relação ao período de fundação das igrejas, ora de ênfase em relação a alguns aspectos do seu corpo teológico ou doutrinário (veja, entre outros Freston 1994 e Mariano 1999).

${ }^{2}$ Como tem sido prática entre muitos estudiosos, adotarei a sigla "IURD" para designar esta igreja.

${ }^{3} \mathrm{Na}$ impossibilidade de localizar a $1^{\mathrm{a}}$. edição deste livro, utilizarei para minhas observações sua $4^{\text {a }}$. edição.

${ }^{4}$ Classifica por esse termo o candomblé e a umbanda.

${ }^{5}$ Em 1975, McAlister lançou Crentes endemoniados: a nova heresia.

${ }^{6}$ Por meio da nomeação dessas três entidades, o autor anuncia os três principais sistemas religiosos que serão abordados em seu livro: orixás (candomblé); caboclos (umbanda) e guias (espiritismo).

${ }^{7} \mathrm{Na}$ capa da 13a. edição, de 1996, consta: "2 milhões de exemplares vendidos", mas em várias páginas da Internet contendo informações sobre a Gráfica Universal, editora do livro, esta cifra aparece atualizada.

${ }^{8}$ Ao contrário do livro de McAlister, em que o testemunho da ex-mãe-de-santo Georgina é central (inclusive narrado em $1^{\mathrm{a}}$ pessoa), no de Macedo há inúmeros relatos de ex-adeptos dos cultos afros feitos pelo autor (em $3^{\mathrm{a}}$. pessoa).

${ }^{9}$ A existência desses "cadernos de fundamentos" escritos pelos religiosos como forma de reter os inúmeros detalhes do conhecimento ritual é comum no candomblé (Silva 1995).

${ }^{10}$ Tal como o livro de McAlister, o de Macedo também é dedicado aos pais e às mães-de-santo e tem um capítulo indicando os "passos" para a libertação (seis no primeiro caso e dez no segundo). Um dos capítulos de Orixás, caboclos e guias... tem o mesmo nome de um outro livro de McAlister: Crentes endemoniados.

${ }^{11} \mathrm{Na}$ ordem mítica do candomblé tudo deve começar com Exu e terminar com Oxalá.

${ }^{12}$ A Pombagira representa o princípio feminino de Exu.

${ }^{13}$ Nas religiões afro-brasileiras o simbolismo do sacrifício animal representa a "morte" da vida anterior da iniciada e o seu nascimento para uma vida nova com e no orixá. Pela morte do animal, homens e deuses se aproximam. 
${ }^{14}$ Há ainda outros exemplos, como Conhecendo os cultos afros: umbanda, quimbanda, candomblé, de Milton Vieira da Silva, 1999.

${ }^{15}$ Em Os profetas das grandes religiões, R. R. Soares "condena" 19 fundadores de "falsas doutrinas", como Buda, Confúcio e Maomé. Nessa mesma linha veja, entre outros, Seitas e heresias, de Raimundo de Oliveira, 2004; Resposta às seitas, um manual popular sobre as interpretações equivocadas das seitas, de Norman Geisler e Ron Rhodes, 2004.

${ }^{16}$ Ao se considerar o baixo poder de consumo (material e cultural) dos segmentos populacionais que mais têm se mostrado receptivos à mensagem neopentecostal e as cifras, muitas vezes expressas em milhões, alardeadas sobre o número de exemplares vendidos dessa literatura, vê-se que não é nada desprezível seu poder de fogo. A produção de uma literatura de divulgação religiosa, seja por meio de livros ou jornais, passou a ser um traço característico importante das igrejas neopentecostais, muitas delas constituindo para isso suas próprias editoras. Além da produção impressa, a produção e a venda de material audiovisual também têm sido muito exploradas por essas igrejas.

${ }^{17} \mathrm{O}$ termo "ataque" está sendo usado aqui no sentido de uma investida pública de um grupo religioso contra outro. Certamente as razões desse ataque se justificam, do ponto de vista do "atacante", por convicções religiosas. E deste ponto de vista, o termo é visto como sinônimo de "evangelização", "libertação" etc. Faz parte, aliás, de um léxico "belicoso", no qual figuram outros termos como "batalha", "guerra santa", "soldado de Jesus" e outros, presentes no discurso neopentecostal que descreve suas ações contra o demônio e os sistemas religiosos que supostamente o cultuam. Do ponto de vista dos grupos afro-brasileiros, obviamente o ataque possui inúmeros outros significados, sendo visto como sinônimo de "intolerância religiosa", "preconceito", "discriminação" etc.

${ }^{18} \mathrm{O}$ Globo, 7/7/89. Muitas fontes jornalísticas citadas aqui foram utilizadas inicialmente por Ricardo Mariano em Neopentecostais. Sociologia do novo pentecostalismo no Brasil, 1999.

${ }^{19}$ Folha de S. Paulo, 28/6/1988.

${ }^{20}$ A Tarde, $16 / 4 / 2003$.

${ }^{21}$ Folha de S. Paulo, 14/12/2003. O uso do sal grosso e do enxofre para expulsar "demônios" baseia-se na bíblia; nela, esses elementos aparecem como purificadores ou redentores dos praticantes do mal. Com estes elementos, Deus puniu, por exemplo, os habitantes de Sodoma, Gomorra, Admá e Zeboim, tornando os solos dessas cidades inférteis (Deuteronômio, 29:23).

${ }^{22}$ É importante lembrar, considerando esse contexto, que sacrifício humano não faz parte dos ritos aceitos pelas religiões afro-brasileiras, o que não impede, entretanto, que em alguns casos, conforme notícias da imprensa (O Estado de S. Paulo, 
22/6/1999; O Dia, 17/8/2000, 21/9/2000, 2/2/2000), os autores desse tipo de crime se identifiquem como adeptos de tais religiões. Nesses casos, enfatizo, não é a prática religiosa que determina o crime (ainda que este se apresente com certas características dos ritos sacrificiais das religiões afro-brasileiras), mas é o criminoso que, a partir de uma ótica particular, extrai do sistema religioso justificativas para o crime. Reproduções de notícias sobre esses crimes (com suas fotos impactantes) proliferam em materiais de divulgação neopentecostal, como o já citado livro de Edir Macedo. E sob o termo de "magia negra" nomeiam-se esses fatos sobrepondo o preconceito religioso ao preconceito de cor.

${ }^{23}$ Boletim da Comissão Maranhense de Folclore, dez/2001. Relato pessoal dos antropólogos Sergio e Mundicarmo Ferretti, presentes no momento do ocorrido.

${ }^{24}$ Folha de S. Paulo, 3/10/2002. Veja também o livro do ex-pastor Mario Justino (1995), Nos bastidores do reino: a vida secreta na Igreja Universal do Reino de Deus, no qual o autor declara que era prática durante os cultos quebrar imagens católicas e queimar roupas de candomblé e colares de miçangas levados pelos filhos-de-santo que se convertiam.

${ }^{25}$ A Tarde, 27/12/2004 e 10/1/2005.

${ }^{26}$ Folha de S. Paulo, 14/12/2003.

${ }^{27}$ O Globo, 23/10/1988.

${ }^{28}$ A Tarde, $10 / 1 / 2005 ; 21 / 2 / 2005$.

${ }^{29}$ Revista Veja, 30/11/88.

${ }^{30}$ Informação de Leandro Braga, maestro dirigente da organização na Lista de discussão Samba e Choro, 2004 (www.samba-choro.com.br).

${ }^{31}$ www.capoeira.jex.com.br.

${ }^{32}$ Lei 10.639, sancionada em 9/1/2003, que altera a Lei de Diretrizes e Bases da Educação Nacional (LDB). Maiores informações em: http://www.mec.gov.br/cne/ pdf/003.pdf

${ }^{33}$ Jornal de Pato Branco, 6/6/2003.

${ }^{34}$ Trata-se da Coleção História paratodos, Ensino Fundamental, Editora Scipione, de autoria de Maria da Conceição Carneiro de Oliveira, 2004.

${ }^{35} \mathrm{O}$ texto da proposição da Lei de número 11.915, aprovada em 21 de maio de 2003, incluía o seguinte parágrafo que não foi aprovado: "Artigo II - É vedado: [...] Parágrafo XII - Realizar espetáculos, esporte, tiro ao alvo, cerimônia religiosa, feitiço, rinhadeiros, ato público ou privado, que envolvam maus tratos ou a morte de animais, 
bem como lutas entre animais da mesma espécie, raça, de sua origem exótica ou nativa, silvestre ou doméstica ou de sua quantidade" (grifos meus). Disponível em: http://www.xapana.com.br/matriz.htm.

${ }^{36}$ A sentença foi assim determinada pelo juiz em 30/4/2003: "Nos termos do art. 77 do Código Penal, entendendo ser incabível a substituição prevista no art. 44 do Código Penal pela personalidade intransigente da ré, concedo-lhe, contudo, a suspensão condicional da pena privativa de liberdade, por quatro anos, mediante as seguintes condições: $1^{\circ}$ ) apresentar-se bimestralmente no cartório para justificar a sua atividade profissional e manter atualizado o seu endereço; $2^{\circ}$ ) limitação e cessação das atividades da Sociedade de umbanda Oxum e Xangô que, nos sábados, não poderá manter atividades espirituais e festivas a partir das 24:00 horas e, nos demais dias de semana, até no máximo às 22:00 horas; $3^{\circ}$ ) proibição de sacrifícios de animais de grande porte na sede da sociedade, eis que localizada em zona central e residencial, sendo proibido pelas normas sanitárias e de saúde pública o abate de animais em locais deste tipo". Em 31/10/2003, a justiça acatou parcialmente um recurso impetrado e retirou a sentença anterior aplicando uma multa de R \$ 240. Disponível em: (http://www.oxum.com.br/mobilizacao.asp).

${ }^{37}$ Jornal do Brasil, 21/11/1988.

${ }^{38}$ O Globo, 1/8/1989; O Estado de S. Paulo, 27/8/1992. Cf. Mariano, 1999:120.

${ }^{39} \mathrm{O}$ autor da agressão foi condenado com base no Artigo 208 do Código Penal (vilipêndio a objeto de culto religioso e estímulo ao preconceito religioso) a 2 anos e 2 meses de prisão. Folha de S. Paulo, 1/5/1997.

${ }^{40}$ A Tarde, $10 / 1 / 2005$.

${ }^{41}$ Entre estas entidades estão Aganju (Afro Gabinete de Articulação Jurídica) e Anaas (Associação dos Advogados Afro-descendentes). A Tarde, 10/1/2005.

${ }^{42}$ A maioria desses processos tem sido encaminhada pelo promotor Lidivaldo Reaiche Raimundo Britto, titular da $2^{a}$. Promotoria de Justiça de Cidadania de Salvador, do Ministério Público. Essa promotoria tem tido um papel ativo nas ações contra a intolerância religiosa naquele estado (A Tarde, 21/2/2005).

${ }^{43}$ A Tarde, 10/1/2005

${ }^{44}$ A ação foi movida pelo Ministério Público Federal e outros (Instituto Nacional de Tradição e Cultura Afro-brasileira - Intecab e Centro de Estudos das Relações de Trabalho e da Desigualdade - CEERT). Folha de S. Paulo, 27/5/2005.

${ }^{45}$ Veja, 26/9/1992.

${ }^{46}$ Folha Universal, ano VII, n.390, set./out. de 1999. 
${ }^{47}$ A Tarde, 7/7/2005.

${ }^{48}$ Em 2005, a sentença proferida em julgamento de segunda instância reduziu este valor para $\mathrm{R} \$ 960.000$, o teto praticado pelo Tribunal de Justiça do Estado (A Tarde, 12/1/2003; 7/7/2005).

${ }^{49}$ A Tarde, 10/1/2005.

${ }^{50} \mathrm{O}$ Dia, 31/3/2004. Como foi mencionado, o ataque às religiões afro-brasileiras, mesmo não tendo explicitamente este objetivo, acaba reforçando o preconceito e a discriminação contra negros.

${ }^{51}$ Folha de S. Paulo, 3/10/2002.

${ }^{52}$ Processo movido contra dois pastores da Missão Evangélica Global (http:// www.meg.org.br/) acusados de perturbarem as festividades em homenagem a Iemanjá na Praia Grande.

${ }^{53}$ O Estado de S. Paulo, 29/3/89.

${ }^{54}$ O Estado de S. Paulo, 18/8/89.

${ }^{55}$ Sobre este aspecto é interessante consultar o "Relatório elaborado pela Igreja Presbiteriana do Brasil visando o esclarecimento de seus membros referente à fé e prática da Igreja Universal do Reino de Deus". Disponível em: (http://www.cacp. org.br/iurd.htm).

${ }^{56}$ Veja, por exemplo, de R. R. Soares, os livros Exija seus direitos e Como tomar posse da benção. No site de vendas da Igreja Internacional da Graça, eles são assim anunciados, respectivamente: "Como ter, usar e desfrutar de tudo o que Cristo conquistou é um desafio que está à frente do cristão"; "Você é quem decide o que terá ou não. Aprenda a tomar posse das maravilhas que Deus já nos preparou". Disponível em: (http://www.gracaeditorial.com.br/). Cf. Mariano 1999:154.

${ }^{57}$ Sobre este cruzamento de ritos e de cosmogonias que chamei de "afro-pentecostais", ver Silva 2005b.

${ }^{58}$ No trabalho de Ronaldo Almeida (1996) há uma análise de como essa inversão simetricamente oposta ocorre nos ritos de expulsão dos demônios. 


\section{Referências bibliográficas}

ABIMBOLA, Wande. 1973. "The ioruba concept of human personality". In: La notion de personne en Afrique Noire. Colloques Internationale du C.N.R.S., 544:73-89

AMARAL, Rita. 2002. Xirê! O modo de crer e de viver no candomblé. Rio de Janeiro: Educ/ Pallas.

ALMEIDA, Ronaldo. 1996. A universalização do Reino de Deus. Dissertação de Mestrado em Antropologia Social, Unicamp, São Paulo.

BIRMAN, Patrícia. 2001. "Conexões políticas e bricolagens: questões sobre pentecostalismo". In: P. Sanchis (org.), Fiéis \& cidadãos: percursos de sincretismo no Brasil. Rio de Janeiro: EdUERJ. pp. 59-86.

1994. "Cultos de possessão e pentecostalismo no Brasil: passagens". Religião e Sociedade, 17(1/2):90-109. 1997. "Males e malefícios no discurso neopentecostal". In: P. Birman; R. Novaes \& S. Crespo (orgs.), O mal à brasileira. Rio de Janeiro EdUERJ. pp. 62-80.

BRUMANA, Fernando e MARTÍNEZ, Elda. 1991. Marginália sagrada. Campinas: Editora da Unicamp.

CAMARGO, Cândido Procópio de. 1961. Kardecismo e umbanda. São Paulo: Pioneira.

CAVALCANTI, Maria Laura Viveiros de Castro. 1990. "Espiritismo". In Sinais dos tempos: diversidade religiosa no Brasil. Cadernos do ISER, 23:147-155.

DAMATTA, Roberto. 1979. Carnavais, malandros e heróis: Para uma sociologia do dilema brasileiro. Rio de Janeiro: Zahar.

FRESTON, Paul. 1994. "Breve história do pentecostalismo brasileiro". In:
A. Antoniazzi et alii (orgs.), Nem anjos, nem demônios. Petrópolis: Vozes. pp. 67-159.

FRY, Peter H. 1982. "Manchester, século XIX, e São Paulo, século XX: dois movimentos religiosos. In: Para inglês ver. Rio de Janeiro: Zahar. pp. 21-46. . 2005. A persistência da raça. Rio de Janeiro: Civilização Brasiliense.

e HOWE, Gire Nigel. 1975.

"Duas respostas à aflição: umbanda e pentecostalismo". Debate e Crítica, 6:75-94.

GEISLER, Geisler e RHODES, Ron. 2004 Resposta às seitas. Um manual popular sobre as interpretações equivocadas das seitas. Rio de Janeiro: Casa Publicadora da Assembléia de Deus.

GIUMBELLI, Emerson. 2001. "Liberdade religiosa no Brasil contemporâneo: uma discussão a partir do caso da Igreja Universal do Reino de Deus". In: R. Kant de Lima (org.). Antropologia e direitos humanos. Niterói: EdUFF. pp. 75-96. . 2002. "Zélio de Morais e as origens da umbanda". In: V. Gonçalves da Silva (org.), Caminhos da alma. São Paulo: Selo Negro. pp. 183-218.

GOLDMAN, Marcio. 1985. "A construção ritual da pessoa: a possessão no candomblé". Religião e Sociedade, 12(1):22-55.

GOMES, Wilson S. 1994. "Nem anjos, nem demônios". In: A. Antoniazzi et alii (orgs.), Nem anjos, nem demônios. Petrópolis: Vozes. pp. 225-270.

JUNGBLUT, Airton. 2003. "Os domínios do maligno e seu combate: notas sobre algumas percepções evangélicas atuais acerca do mal". In: B. Lewgoy (org.), Debates do NER, IFCH/ UFRGS, 4:35-42. 
JUSTINO, Mario. 1995. Nos bastidores do reino: a vida secreta na Igreja Universal do Reino de Deus. São Paulo: Geração Editorial.

LÉVI-STRAUSS, Claude. 1970. Antropologia estrutural. Rio de Janeiro: Tempo Brasileiro.

LEWIS, Ion M. 1971. Êxtase religioso. São Paulo: Perspectiva.

MACEDO, Edir. 1996 [1988]. Orixás, caboclos e guias: deuses ou demônios? Rio de Janeiro: Editora Universal. 2004. O perfeito sacrifício. Rio de Janeiro: Editora Gráfica Universal.

MARIANO, Ricardo. 1996. "Igreja Universal do Reino de Deus: a magia institucionalizada". Revista USP, 31:120-131.

1999. Neopentecostais: sociologia do novo pentecostalismo no Brasil. São Paulo: Loyola. . 2003. "Guerra espiritual: o protagonismo do diabo nos cultos neopentecostais". In: B. Lewgoy (org.). Debates do NER, 4(4):21-34.

MARIZ, Cecília. 1994. "Libertação e ética. Uma análise do discurso de neopentecostal que se recuperaram do alcoolismo". In: A. Antoniazzi et alii. Nem anjos, nem demônios. Petrópolis: Vozes. pp. 204-224. 1999. "A teologia da batalha espiritual: uma revisão da bibliografia". Revista Brasileira de Informação Bibliográfica em Ciências Sociais, $47(1): 33-48$.

2000. "O demônio e os pentecostais no Brasil". In: R. Cipriani; P. Eleta e A. Nesti (orgs.). Identidade e mudança na religiosidade latinoamericana. Petrópolis: Vozes. pp. 251-264.

MATORY, J. Lorand. 1988. "Homens montados: homossexualidade e simbolismo da possessão nas religiões afro-brasileiras". In: J. J. Reis. Escra- vidão e invenção da liberdade. São Paulo: Brasiliense. pp. 215-231.

MATTA E SILVA, W. W. 1960. Umbanda de todos nós. Rio de Janeiro: Freitas Bastos.

McALISTER, Robert. 1983 [1968]. Mãede-santo. $4^{\mathrm{a}}$.ed. Rio de Janeiro: Editora Carisma.

OLIVEIRA, Maria da Conceição C. 2004. História paratodos. $2^{\text {a }}$ série, Ensino Fundamental. São Paulo: Scipione.

OLIVEIRA, Marco Davi. 2004. A religião mais negra do Brasil. São Paulo: Mundo Cristão.

OLIVEIRA, Raimundo de. 2004. Seitas e heresias. Rio de Janeiro: Casa Publicadora da Assembléia de Deus.

ORO, Ari Pedro. 1997. "Neopentecostais e afro-brasileiros: quem vencerá esta guerra?". Debates do NER, 1:10-37. .2001. "Neopentecostalismo: dinheiro e magia". Ilha. Revista de Antropologia, 3(1):71-86. , CORTEN, André e DOZON, Jean-Pierre. 2003. Igreja Universal do Reino de Deus. Os novos conquistadores da fé. São Paulo: Paulinas.

PIERUCCI, Antônio Flávio e PRANDI, Reginaldo. 1996. A realidade social das religiões no Brasil. São Paulo: Hucitec.

ROLIM, Francisco Cartaxo. 1990. "Igreja Pentecostal Deus é Amor". In: Sinais dos tempos: diversidade religiosa no Brasil. Cadernos do ISER, 23:59-63.

SAHLINS, Marshall. 1979. Cultura e razão prática. Rio de Janeiro: Zahar.

SANCHIS, Pierre. 2001. "Religiões, religião... alguns problemas do sincretismo no campo religioso brasileiro". In: Fiéis \& cidadãos: percursos de sincretismo no Brasil. Rio de Janeiro: EdUERJ. pp. 9-57.

SILVA, Milton Vieira. 1999. Conhecendo os cultos afros: umbanda, quimbanda, candomblé. Curitiba: A. D. Santos Editora. 
SILVA, Vagner Gonçalves da. 1995. Orixás da metrópole. Petrópolis: Vozes. 2005a. Candomblé e umbanda. São Paulo: Selo Negro. . 2005b. "Concepções religiosas afro-brasileiras e neopentecostais: uma análise simbólica". Revista USP, 67:150-175.

SOARES, Mariza de Carvalho. 1990. "Guerra santa no país do sincretismo". In: Sinais dos tempos: diversidade religiosa no Brasil. Cadernos do ISER, 23:75-104.

SOARES, R. R. 1984. Espiritismo: a magia do engano. Rio de Janeiro: Graça Editorial.

\section{Resumo}

Neste trabalho, pretendo analisar as relações de proximidade e antagonismo existentes entre o neopentecostalismo e as religiões afro-brasileiras, e suas conseqüências na transformação do imaginário social brasileiro construído a partir dos valores existentes nesses dois campos.

Palavras-chave: Candomblé, Umbanda, Neopentecostalismo, Conflito Religioso, Símbolos Africanos.
. s/d. Exija seus direitos. Rio de Janeiro: Graça Editorial.

. s/d. Como tomar posse das bênçãos. Rio de Janeiro: Graça Editorial.

. s/d. Os profetas das grandes religiões. Rio de Janeiro: Graça Editorial.

TAUSSIG, Michael. 1987. "O batismo do dinheiro e o segredo do capital". Religião e Sociedade, 14(2):18-31.

THOMAS, Keith. 1991. Religião e declínio da magia. São Paulo: Companhia das Letras.

TRINDADE, Liana. 1985. Exu: poder e perigo. São Paulo: Ícone.

\section{Abstract}

In this work, I analyze the relations of proximity and antagonism between Neo-Pentecostalism and Afro-Brazilian religions, and their consequences for the transformation of the Brazilian social imaginary constructed on the basis of values derived from these two fields.

Key words: Candomblé, Umbanda, NeoPentecostalism, Religious Conflict, African Symbols 